\title{
Growth and Yield of Aerobic Rice as Influenced by Different Weed Management Practices in Tripura, India
}

\author{
M. Chakraborti ${ }^{1 *}$, B. Duary ${ }^{2}$ and M. Datta ${ }^{3}$ \\ ${ }^{1}$ Krishi Vigyan Kendra, West Tripura, ICAR (RC) for NEH Region, India \\ ${ }^{2}$ Department of Agronomy, Palli Siksha Bhavana, Visva-Bharati, Sriniketan, India \\ ${ }^{3}$ College of Agriculture, Tripura, India \\ *Corresponding author
}

\begin{abstract}
A B S T R A C T
A field experiment was conducted at Krishi Vigyan Kendra (KVK), South Tripura during the kharif season of 2013 and 2014 to study the influence of weed management practices

Keywords

Aerobic rice, weed management, pendimethalin, weed dry weight, bispyribac sodium

Article Info

Accepted:

25 April 2018

Available Online:

10 June 2018 on growth and yield of aerobic rice. The experiment consisting of twelve treatments was laid out in a randomized complete block design with three replications. The common weed flora found in the experimental field were Amaranthus viridis, hedyotis corymbosa, Spilanthes acmella, Ludwigia parviflora, Cleome rutidosperma, Malvaestrum coromandalinum among the broad leaf weeds, Digitaria sanguinalis among grasses and Cyperus iria among sedges. Although hand weeding thrice at 15, 30 and 45 DAS recorded the lowest weed dry weight for all types of weed, higher values of growth parameters, yield and yield attributing parameters of upland rice but it was not economically viable. Among the various management practices, the treatment pendimethalin at $1.0 \mathrm{~kg} \mathrm{ha}^{-1}$ at 2 DAS + bispyribac sodium at $25 \mathrm{~g} \mathrm{ha}^{-1}$ at 20 DAS recorded the highest net return and return per rupee invested and appeared to be the most promising and remunerative weed management practice and followed by pendimethalin at $1.0 \mathrm{~kg} \mathrm{ha}^{-1}$ at $2 \mathrm{DAS}+$ one hand weeding at 30 DAS for direct seeded rice under Tripura condition.
\end{abstract}

\section{Introduction}

Rice is the staple food of India. It plays a crucial role in the economic and social stability of the world. The resources for rice production like-land, water, nutrients, and labour are becoming scarce. Meeting rice demand of ever increasing population is of great challenge in near future. Transplanting of rice is an age old practice but in the recent years shortage of labour made the task difficult (Budhar and Tamilselven, 2002). Therefore direct seeded rice is gaining popularity over the transplanted rice. Directseeded rice (DSR) has several advantages over puddled transplanted rice like easier planting, timely sowing, less drudgery, early crop maturity by 7-10 days, less water requirement, better soil physical condition for next crop and low production cost and more profit (Kumar and Ladha, 2011). However, weeds are the main biological constraints to the production 
of DSR (Rao et al., 2007; Chauhan and Johnson, 2010) which may cause 60-80\% reduction in grain yield of rice. Hence the present investigation was carried out to study the efficacy of some weed management practices in direct seeded upland rice under Tripura condition.

\section{Materials and Methods}

A field experiment was conducted at Krishi Vigyan Kendra, South Tripura during the kharif (wet) season of 2013 and 2014 to study the influence of different weed management practices in direct seeded rice under aerobic condition in Tripura, India. Twelve treatments viz. Pendimethalin at $1.0 \mathrm{~kg} \mathrm{ha}^{-1}$ at 2 DAS $\left(\mathrm{T}_{1}\right)$, Bispyribac sodium at $25 \mathrm{~g} \mathrm{ha}^{-1}$ at 25 DAS $\left(\mathrm{T}_{2}\right)$, Pendimethalin at $1.0 \mathrm{~kg} \mathrm{ha}^{-1}$ at 2 DAS+ one hand weeding at 30 DAS $\left(T_{3}\right)$, Pendimethalin at $1.0 \mathrm{~kg} \mathrm{ha}^{-1}$ at $2 \mathrm{DAS}+$ bispyribac sodium at $25 \mathrm{~g} \mathrm{ha}^{-1}$ at $20 \mathrm{DAS}\left(\mathrm{T}_{4}\right)$, Metsulfuron methyl+ chlorimuron ethyl (Almix) at $4 \mathrm{~g}$ at 10 DAS followed by Bispyribac sodium at $25 \mathrm{~g}$ at $20 \mathrm{DAS}\left(\mathrm{T}_{5}\right)$, Pyrazosulfuron ethyl at $25 \mathrm{~g} \mathrm{ha}^{-1}$ at 3 DAS followed by bispyribac sodium at $25 \mathrm{~g}$ at 20 DAS $\left(\mathrm{T}_{6}\right)$, Fenoxaprop-p-ethyl at $60 \mathrm{~g} \mathrm{ha}^{-1}+$ metsulfuron methyl+ chlorimuron ethyl (Almix) at $4 \mathrm{~g} \mathrm{ha}^{-1}$ at $15 \mathrm{DAS}\left(\mathrm{T}_{7}\right)$, Stale seed bed + smother crop (cowpea) $\left(\mathrm{T}_{8}\right)$ in between two rows of rice, Stale seed bed + one hand weeding at $30 \mathrm{DAS}\left(\mathrm{T}_{9}\right)$, Sesbania (broadcast) (a $25 \mathrm{~kg} \mathrm{ha}^{-1}$ during sowing of rice $+2,4-\mathrm{D}$ at $500 \mathrm{~g} \mathrm{ha}^{-1}$ at $25 \mathrm{DAS}\left(\mathrm{T}_{10}\right)$, Hand weeding at 15,30 and 45 DAS $\left(T_{11}\right)$, Weedy check $\left(T_{12}\right)$ were assigned in a randomized block design replicated thrice. Rice variety NDR-97 was used for the experimental purpose with recommended package of practices.

The upland rice was fertilized as per recommended package of practices in Tripura. Five tonnes of Farm Yard Manure were applied at the time of field preparation for both the crop. Chemical fertilizers were applied to meet $60 \mathrm{~kg}$ nitrogen in the form of urea, $40 \mathrm{~kg}$ phosphorus in the form of single superphosphate and $40 \mathrm{~kg}$ potassium in the form of muriate of potash in the rice.

Weed counts at different stages (15, 30, 60 and at harvest stage) was taken by placing quadrat at random from three sites in each plot and calculating the average. Weed sample from each of the quadrat was taken, grouped into grasses, broad leaved weed and sedges, dried and weighed. Weed dry matter was expressed category wise in $\mathrm{g} \mathrm{m}^{-2}$. Data on growth parameters, yield attributes and yield of rice were taken. Economics of different weed management practices was also calculated. The data generated from the experiment were subject to analysis of variance (ANOVA) as applied to randomized block design describe by Cochran and Cox, 1965.

\section{Results and Discussion}

\section{Effect on weeds}

The common weed flora found in the experimental field were Amaranthus viridis, Hedyotis corymbosa, Spilanthes acmella, Ludwigia parviflora, Cleome rutidosperma, Malvestrum coromondalianeum among the broad leaf weeds, Digitaria sanguinalis among grasses and Cyperus iria among sedges. Similar weed flora in direct seeded rice was also reported by Duary et al., 2005; Duary and Mukherjee, 2013; Duary et al., 2016. The effect of various weed management practices on dry weight of grasses, broadleaved weeds, sedges and all weeds showed highly significant differences at 60 DAS (Table 1). There was no remarkable changes in dry weight of grasses, broad leaved, sedges and total weeds between the two years. It is evident from the data that, in both the year weed dry weight of grasses, broadleaved, sedges and total weed was the highest in weedy check $\left(\mathrm{T}_{12}\right)$ in comparison to other treatment tested (Table 1 and 2). The 
uncontrollable weed growth exploited the available nutrients and water, resulting in better growth and dry matter production of it. Similar result has been observed by Duary et al., 2005; Sunil et al., 2010 who reported significantly higher weed population and weed dry weight under unweeded check in aerobic rice. The lowest dry weight was recorded with hand weeding thrice at 15, 30 and 45 DAS $\left(\mathrm{T}_{11}\right)$ and this treatment was closely followed by pendimethalin + one hand weeding $\left(\mathrm{T}_{3}\right)$ and pendimethalin + bispyribac sodium $\left(\mathrm{T}_{4}\right)$. The result was in conformity with the findings of Duary et al., 2005; Bhurer et al., 2013.

\section{Effect on growth parameters of rice}

It was clear from the data presented in Table 2 that different weed management practices have positive effect on plant height, numbers of tiller, leaf area index and dry matter accumulation.

Among the various treatments, hand weeding thrice at 15, 30 and 45 DAS $\left(T_{11}\right)$ recorded the highest plant height and number of tillers $\mathrm{m}^{-2}$ and this treatment was at par with pendimethalin + one hand weeding $\left(\mathrm{T}_{3}\right)$ and pendimethalin + bispyribac sodium $\left(\mathrm{T}_{4}\right)$. Similar trend was followed in case of leaf area index and drymatter accumulation.

Effect on yield parameters, yield and economics

It was clear from the data presented in Table 3 that different weed management practices did have a positive role in determining the yield and other yield attributing characters of upland rice. Among the different treatments, hand weeding thrice at 15,30 and 45 DAS $\left(T_{11}\right)$ recorded the highest number of panicles $\mathrm{m}^{-2}$, number of grains panicle ${ }^{-1}$, grain and straw yield $^{-1}$, harvest index during both the years.
This treatment was at par with pendimethalin + one hand weeding $\left(\mathrm{T}_{3}\right)$ and pendimethalin + bispyribac sodium $\left(\mathrm{T}_{4}\right)$. Pendimethalin is an excellent herbicide showing its better efficacy since last three decades (Das and Duary, 1998). The efficacy of pendimethalin in combination with hand weeding was reported effective in controlling weed in dry direct seeded rice by Ramamoorthy et al., 1998; Singh et al., 2005; Duary et al., 2016. Effective and timely weed management under these treatments reduced the dry weight of weeds which facilitated the crop to have sufficient space, light, nutrient and moisture and thus the number of panicles $\mathrm{m}^{-2}$, number of grains panicle ${ }^{-1}$ and finally the grain and straw yield was increased. Test weight of rice was not influenced by the weed management practices.

Among the different treatments, pendimethalin + bispyribac sodium $\left(\mathrm{T}_{4}\right)$ recorded the highest net return and return per rupee invested and it was at par with pendimethalin + one hand weeding $\left(\mathrm{T}_{3}\right)$. The result of the present study revealed that the remuneration from the rice crop was highly dependent on weed management practices adopted. Pendimethalin at $1.0 \mathrm{~kg} \mathrm{ha}^{-1}$ at 2 DAS + bispyribac sodium at $25 \mathrm{~g} \mathrm{ha}^{-1}$ at 20 DAS $\left(\mathrm{T}_{4}\right)$ recorded the highest net return (Rs. 23847/- in the first year and Rs. 26010/- in the second year) and return per rupee invested (2.02 and 2.11) in both the years and was found to be the most remunerative weed management practices. The herbicide pendimethalin at $1.0 \mathrm{~kg} \mathrm{ha}+$ one hand weeding at 30 DAS $\left(\mathrm{T}_{3}\right)$ registered net return of Rs. 21427/- and 25573/- in the first year and second year respectively and was the next best treatment. This is simply due to higher grain and straw yield of the crop obtained from these treatments. Similar result was reported by Yakadri et al., 2016. 
Int.J.Curr.Microbiol.App.Sci (2018) 7(6): 3715-3721

Table.1 Dry weight of grasses, broad leaved, sedges and total weed at 60 DAS

\begin{tabular}{|c|c|c|c|c|c|c|c|c|}
\hline & \multicolumn{9}{|c|}{ Treatment dry weight $\left(\mathbf{g m}^{-2}\right)$} \\
& \multicolumn{2}{|c|}{ Grasses } & \multicolumn{2}{|c|}{ Broad leaved } & \multicolumn{2}{c|}{ Sedges } & \multicolumn{2}{|c|}{ Total weed } \\
\hline & $\mathbf{2 0 1 3}$ & $\mathbf{2 0 1 4}$ & $\mathbf{2 0 1 3}$ & $\mathbf{2 0 1 4}$ & $\mathbf{2 0 1 3}$ & $\mathbf{2 0 1 4}$ & $\mathbf{2 0 1 3}$ & $\mathbf{2 0 1 4}$ \\
\hline T1 & 76.91 & 72.02 & 39.49 & 36.45 & 29.17 & 26.15 & 145.57 & 134.61 \\
\hline T2 & 95.69 & 91.08 & 43.90 & 40.72 & 9.09 & 8.49 & 148.67 & 140.28 \\
\hline T3 & 28.39 & 23.21 & 23.55 & 20.40 & 9.39 & 6.49 & 61.33 & 50.10 \\
\hline T4 & 29.85 & 23.84 & 26.01 & 20.50 & 9.58 & 7.48 & 65.44 & 51.82 \\
\hline T5 & 88.81 & 84.29 & 43.33 & 40.55 & 8.89 & 7.71 & 141.03 & 132.55 \\
\hline T6 & 78.70 & 73.94 & 37.39 & 34.65 & 16.77 & 14.08 & 132.87 & 122.67 \\
\hline T7 & 82.44 & 77.88 & 40.74 & 37.34 & 15.90 & 12.85 & 139.08 & 128.07 \\
\hline T8 & 117.16 & 111.51 & 40.44 & 36.94 & 30.40 & 27.72 & 188.00 & 176.17 \\
\hline T9 & 92.95 & 88.03 & 41.89 & 38.38 & 23.76 & 21.19 & 158.60 & 147.60 \\
\hline T10 & 113.14 & 108.87 & 37.18 & 33.88 & 29.76 & 27.30 & 180.08 & 170.05 \\
\hline T11 & 24.89 & 20.12 & 18.99 & 15.63 & 5.14 & 2.84 & 49.02 & 38.59 \\
\hline T12 & 141.09 & 136.27 & 67.67 & 64.66 & 42.81 & 40.51 & 251.57 & 241.44 \\
\hline S. Em $( \pm)$ & 2.64 & 2.61 & 1.42 & 1.38 & 1.15 & 1.14 & 2.82 & 3.05 \\
\hline CD(P=0.05) & 7.76 & 7.66 & 4.16 & 4.05 & 3.37 & 3.35 & 8.26 & 8.96 \\
\hline CV (\%) & 5.66 & 5.96 & 6.41 & 6.83 & 10.37 & 11.70 & 3.53 & 4.14 \\
\hline & & & & & & & & \\
\hline
\end{tabular}

Table.2 Effect of weed control treatments on growth parameters of aerobic rice

\begin{tabular}{|c|c|c|c|c|c|c|c|c|}
\hline \multirow[t]{2}{*}{ Treatment } & \multicolumn{2}{|c|}{$\begin{array}{l}\text { Plant height }(\mathrm{cm}) \\
\text { at harvest }\end{array}$} & \multicolumn{2}{|c|}{$\begin{array}{l}\text { No. of tillers } \mathrm{m}^{-2} \\
\text { harvest at } 60 \\
\text { DAS }\end{array}$} & \multicolumn{2}{|c|}{$\begin{array}{c}\text { Leaf area } \\
\text { index at } 90 \\
\text { DAS }\end{array}$} & \multicolumn{2}{|c|}{$\begin{array}{c}\text { Dry matter } \\
\text { accumulation } \\
\left(\mathrm{g} \mathrm{m}^{-2}\right) \text { at } 90 \text { DAS }\end{array}$} \\
\hline & 2013 & 2014 & 2013 & 2014 & 2013 & 2014 & 2013 & 2014 \\
\hline $\mathrm{T1}$ & 73.97 & .42 & 299.60 & 258.80 & 2.20 & 2.21 & 729.33 & 835.67 \\
\hline $\mathrm{T2}$ & 77.48 & 3.61 & 289.47 & 294.00 & 2.38 & 2.38 & 50.00 & 839.00 \\
\hline T3 & 87.45 & 85.60 & 370.27 & 377.73 & 3.00 & 2.84 & 915.67 & 989.67 \\
\hline $\mathrm{T4}$ & 88.17 & 82.89 & 358.13 & 380.00 & 3.02 & 2.62 & 921.83 & 1001.67 \\
\hline T5 & 79.55 & 74.43 & 276.80 & 313.07 & 2.77 & 2.37 & 761.33 & 876.67 \\
\hline T6 & 75.96 & 80.22 & 304.67 & 303.07 & 2.43 & 2.43 & 853.00 & 934.10 \\
\hline $\mathrm{T7}$ & 73.15 & 67.78 & 246.67 & 247.60 & 2.65 & 2.39 & 701.00 & 765.00 \\
\hline T8 & 71.58 & 68.84 & 259.20 & 244.40 & 2.37 & 2.39 & 709.00 & 799.33 \\
\hline T9 & 74.39 & 73.22 & 281.87 & 312.93 & 2.47 & 2.37 & 759.67 & 880.67 \\
\hline T10 & 70.18 & 69.21 & 245.60 & 271.33 & 2.42 & 2.37 & 687.67 & 840.00 \\
\hline T11 & 53 & 86.54 & 363.33 & 381.73 & 3.03 & 2.90 & 959.83 & 1014.67 \\
\hline T12 & 52.19 & 56.29 & 165.73 & 162.67 & 1.72 & 1.32 & 489.17 & 470.00 \\
\hline S. Em & J.2J & & 16.42 & 14.67 & 0.12 & 0.11 & 14.01 & 16.03 \\
\hline $\mathrm{CD}(\mathrm{P}=0.05)$ & 9.43 & $6 .^{\circ}$ & 48.17 & 43.02 & 0.34 & 0.33 & 41.08 & 47.03 \\
\hline CV (\%) & 7.32 & 5.39 & 9.86 & 8.59 & 8.45 & 8.13 & 3.15 & 3.25 \\
\hline
\end{tabular}


Table.3 Effect of weed control treatment on yield attributes and yield of rice

\begin{tabular}{|c|c|c|c|c|c|c|c|c|c|c|c|c|c|c|c|c|}
\hline \multirow[t]{2}{*}{ Treatment } & \multicolumn{2}{|c|}{ No. of panicles $\mathrm{m}^{-2}$} & \multicolumn{2}{|c|}{$\begin{array}{l}\text { No. of filled } \\
\text { grains } \\
\text { panicle }^{-1}\end{array}$} & \multicolumn{2}{|c|}{$\begin{array}{c}\text { Test weight } \\
\text { (g) }\end{array}$} & \multicolumn{2}{|c|}{$\begin{array}{c}\text { Grain yield } \\
\qquad\left(\mathbf{t ~ h a}^{-1}\right)\end{array}$} & \multicolumn{2}{|c|}{$\begin{array}{c}\text { Straw yield } \\
\left(\mathbf{t ~ h a}^{-1}\right)\end{array}$} & \multicolumn{2}{|c|}{$\begin{array}{l}\text { Harvest } \\
\text { index }(\%)\end{array}$} & \multicolumn{2}{|c|}{$\begin{array}{c}\text { Net return } \\
\left(\text { Rs. ha }{ }^{-1}\right)\end{array}$} & \multicolumn{2}{|c|}{$\begin{array}{l}\text { Return } \\
\text { rupee }^{-1} \\
\text { invested }\end{array}$} \\
\hline & 2013 & 2014 & 2013 & 2014 & 2013 & 2014 & 2013 & 2014 & 2013 & 2014 & 2013 & 2014 & 2013 & 2014 & 2013 & 2014 \\
\hline $\mathbf{T 1}$ & 240.54 & 198.16 & 52.95 & 50.66 & 23.34 & 23.43 & 2.15 & 2.36 & 3.89 & 4.21 & 35.60 & 35.82 & 14297 & 1.55 & 1.55 & 1.70 \\
\hline $\mathbf{T 2}$ & 232.90 & 235.13 & 44.03 & 54.68 & 23.28 & 23.36 & 2.21 & 2.26 & 3.65 & 4.22 & 37.69 & 34.77 & 11830 & 1.49 & 1.49 & 1.54 \\
\hline T3 & 324.17 & 335.10 & 65.23 & 69.66 & 23.45 & 23.25 & 3.30 & 3.59 & 5.03 & 5.28 & 39.62 & 39.82 & 25573 & 1.81 & 1.81 & 1.96 \\
\hline $\mathrm{T} 4$ & 317.24 & 336.27 & 66.67 & 68.01 & 23.19 & 23.23 & 3.26 & 3.41 & 4.87 & 5.17 & 40.14 & 39.73 & 26010 & 2.02 & 2.02 & 2.11 \\
\hline T5 & 216.54 & 253.73 & 45.45 & 56.19 & 23.59 & 23.03 & 2.49 & 2.65 & 3.72 & 4.65 & 40.14 & 36.29 & 16542 & 1.60 & 1.60 & 1.73 \\
\hline T6 & 249.42 & 291.24 & 60.35 & 61.14 & 22.87 & 23.10 & 2.71 & 2.80 & 4.04 & 4.81 & 40.15 & 36.68 & 18490 & 1.73 & 1.73 & 1.82 \\
\hline T7 & 182.93 & 168.85 & 49.15 & 51.81 & 23.20 & 23.39 & 1.89 & 1.98 & 3.82 & 3.98 & 32.97 & 33.18 & 9188 & 1.39 & 1.39 & 1.45 \\
\hline $\mathrm{T} 8$ & 188.75 & 173.30 & 52.18 & 52.82 & 23.26 & 23.52 & 1.86 & 2.01 & 3.79 & 4.01 & 32.92 & 33.27 & 6613 & 1.19 & 1.19 & 1.28 \\
\hline T9 & 228.11 & 259.80 & 57.31 & 54.80 & 23.51 & 23.42 & 1.86 & 2.10 & 3.71 & 3.89 & 33.42 & 35.10 & 5203 & 1.07 & 1.07 & 1.20 \\
\hline T10 & 198.00 & 218.61 & 53.07 & 53.81 & 23.42 & 23.17 & 1.81 & 1.93 & 3.75 & 3.74 & 32.79 & 34.13 & 9083 & 1.38 & 1.38 & 1.46 \\
\hline T11 & 339.36 & 322.18 & 67.67 & 71.28 & 23.28 & 23.50 & 3.45 & 3.60 & 5.16 & 5.43 & 40.33 & 40.57 & 19713 & 1.54 & 1.54 & 1.61 \\
\hline T12 & 119.55 & 101.86 & 32.65 & 33.18 & 23.07 & 23.23 & 0.58 & 0.74 & 2.90 & 2.80 & 16.85 & 20.76 & -3450 & 0.66 & 0.66 & 0.78 \\
\hline S. Em $( \pm)$ & 21.06 & 15.52 & 3.42 & 2.72 & 0.17 & 0.11 & 0.11 & 0.13 & 0.22 & 0.17 & 1.33 & 0.80 & 1783 & 0.07 & 0.07 & 0.08 \\
\hline $\mathrm{CD}(\mathrm{P}=0.05)$ & 61.76 & 45.51 & 10.03 & 7.97 & NS & NS & 0.34 & 0.37 & 0.64 & 0.49 & 3.88 & 2.35 & 5230 & 0.22 & 0.22 & 0.23 \\
\hline CV $(\%)$ & 15.42 & 11.14 & 10.99 & 8.33 & 1.24 & 0.84 & 8.62 & 8.93 & 9.40 & 6.70 & 6.52 & 3.97 & 23.29 & 8.39 & 8.39 & 8.95 \\
\hline
\end{tabular}


Though the rice yield and gross return were the highest under hand weeding at 15, 30 and 45 DAS $\left(\mathrm{T}_{11}\right)$, the data on net income and return per rupee invested showed that it was less remunerative than pendimethalin at 1.0 $\mathrm{kg} \mathrm{ha}^{-1}$ at $2 \mathrm{DAS}+$ bispyribac sodium at $25 \mathrm{~g}$ ha $^{-1}$ at $20 \mathrm{DAS}\left(\mathrm{T}_{4}\right)$ and pendimethalin at 1.0 $\mathrm{kg} \mathrm{ha}^{-1}+$ one manual weeding at $30 \mathrm{DAS}\left(\mathrm{T}_{3}\right)$ which implied that it was uneconomic and unnecessary to give three hand weeding during the entire crop growth. The net income was found negative under weedy check due to greater competition between rice and weed which led to poor growth of the crop, lower grain and straw yield. This again emphasized the importance of weed management in profitable rice production.

This is in conformity with the study conducted by Prashanth et al., 2016 who reported that the lowest net returns and $\mathrm{B}$ : $\mathrm{C}$ ratio was obtained in unweeded check in transplanted rice. Kashid et al., 2015 reported that significantly the highest net return and return per rupee invested was obtained with the pre-emergence application of herbicide integrating with one hand weeding or one post emergence herbicide. Sharma et al., 2004 reported that pendimethalin + one hand weeding and pendimethalin + criss cross sowing + one hand weeding were better than the other treatments in terms of increasing grain, biomass yields and net returns.

Economically viable cropping system is usually accepted by the farming community. In the present study growth and yield of direct seeded uopland rice was highly influenced by the different weed management practices. Among the various treatments, pendimethalin + bispyribac sodium $\left(\mathrm{T}_{4}\right)$ fetched highest net return and return per rupee invested and proved itself to be the most remunerative weed management practices for direct seeded aerobic rice under upland condition in Tripura.

\section{References}

Bhurer, K. P., Yadav, D. N., Ladha, J. K., Thapa, R, B. and Pandey K R. 2013. Efficacy of various herbicides to control weeds in dry direct seeded rice (Oryza sativa L.). Global J. of Biology, Agriculture and Health Sciences (G.J.B.A.H.S), Vol. 2(4): 205-212.

Budhar, M. N. and Tamilselven, N. 2002. Effect of stand establishment techniques on yield and economical low land irrigated rice. Indian J. Agron, 47(1): 57-60.

Chauhan, B. S. and Johnson, D. E. 2010. The role of seed ecology in improving weed management strategies in the tropics. Advances in Agronomy 105: 221-262.

Cochran, W. G. and Cox, G. M. 1965. Experimental Design. John Willey and Sons, Inc. New York.

Das, T. K. and Duary, B. 1998. Pendimethalin; An excellent herbicide for weed control in crops. Intensive Agriculture 36(5-6): 18-20.

Duary, B. and Mukherjee, A. 2013. Distribution pattern of predominant weeds of wet season and their management in West Bengal, India. In: Proceedings $24^{\text {th }}$ Asian-Pacific Weed Science Society Conference, October 22-25, 2013, Bandung, Indonesia. pp. 191-199

Duary, B., Kumar, M. and Teja, K. C. and Dash, S. 2016. Weed management indry direct seeded rice through integrated approaches In: Proceedinngs of $4^{\text {th }}$ International Agronomy Congress, New Delhi, India during Nov, 22-26, 2016 Extended Summeries Vol.1:277-278.

Duary, B., Mondal, D. C. and Hossain, A. 2005. Integrated weed management in direct seeded dry sown rice in lateritic belt of West Bengal. Indian Journal of Weed Science 37(1/2): 101 -102. 
Kashid, N. V., Barhate, K. K. and Bodake, P. S. 2015. Management of weeds in direct seeded rice. Indian Journal of Weed Science 47(2): 110-112.

Kumar, V. and Ladha, J. K. 2011. Directseeding of rice: Recent developments and future research needs. Advances in Agronomy 111: 297-413.

Mukesh, K., Duary, B. and Charan, T. K. 2015. Integrated weed management in direct-seeded rice in lateritic soil of West Bengal. In: Proceedings of $25^{\text {th }}$ APWSS Conference on Weed Science for Sustainable Agriculture, Environment and Biodiversity, Hyderabad, India during 13-16 October, 2015, Vol-III, p.108

Prashanth, R., Kalyana Murthy, K. N., Madhu Kumar, V., Murali, M. and Sunil, C. M. 2016. Bispyribac-sodium influence on nutrient uptake by weeds and transplanted rice. Indian Journal of Weed Science 48(2): 217-219.

Ramamoorthy, K., Arokiaraj, A. and Balasubramanian, A. 1998. Effect of irrigation and chemical weed control on crop yield and nutrient uptake by upland rice and associated weeds under riceblackgram intercropping system. Oryza 33 , pp. 264-268
Rao, A. N., Johnson, D. E., Sivaprasad, B., Ladha, J. K. and Mortimer, A. M. 2007. Weed management in direct-seeded rice. Advances in Agronomy 93: 153255.

Sharma, S. K., Pandey, D. K., Ganagwar, K. S. and Tomar, O. K. 2004. Weed control in direct, dry-seeded rice in India: comparison of seedbed preparation and use of pendimethalin. International Rice Research Notes 29 (2): 30-31.

Singh, S., Bhusan, L., Ladha, J. K., Gupta, R. K., Rao, A. N. and Sivprasad, B. 2005. Weed management in dry seeded rice (Oryza sativa) cultivated in the furrowirrigated raised-bed planting system. www. elsevier.com/locate/cropo.

Sunil, C. M., Shekara, B. G., Kalyanamurthy, K. N. and Shankaralingappa, B. C. 2010. Growth and yield of aerobic rice as influenced by integrated weed management practices. Ind. J.Weed Sci.37:40-44.

Yakadri, M., Madhavi, M., Ramprakash, T. and Leela, R. 2016. Herbicide combinations for control of complex weed flora in transplanted rice. Indian Journal of Weed Science 48(2): 155157.

\section{How to cite this article:}

Chakraborti M., B. Duary and Datta M. 2018. Growth and Yield of Aerobic Rice as Influenced by Different Weed Management Practices in Tripura, India. Int.J.Curr.Microbiol.App.Sci. 7(06): 3715-3721. doi: https://doi.org/10.20546/ijcmas.2018.706.435 